DOI: $10.17516 / 1997-1370-0595$

УДК $316.3 / .4$

\title{
Flow Community, or Why Nobody Speaks "About Migrants" in the Khabarovsk Krai
}

\section{Leonid E. BLiakher* and Alina P. Ivanova}

Pacific National University

Khabarovsk, Russian Federation

Received 07.03.2020, received in revised form 22.04.2020, accepted 08.05.2020

\begin{abstract}
One of the specific features of most Far Eastern territories is the extremely poor (at least in comparison with the European areas of Russia) development of the discourse "about migrants". It remains an element of narrow professional reasoning about migration as a phenomenon. Moreover, it most often refers not to a person who has arrived in the Far East (Khabarovsk Krai), but to a former resident of the region who has left for other places. In relation to people arriving in the region, much more "partitive" terminology is used, in addition, this terminology often does not have an evaluative connotation, in contrast to the concept of "illegal migrant".

In our opinion, the reason for this word usage, which is not quite usual for the whole country, is some peculiarities accompanying creation of a regional community. For the most part of the $20^{\text {th }}$ century and up to now, the region's population enlarged thanks to migrants. Moreover, due to the multi-ethnic nature of the USSR, these newcomers belonged to very different ethnic groups. Meanwhile, the outflow of the population, which did not stop even in the most prosperous years, led to the fact that every approximately 20 years the composition of the population changed very significantly. As a result, the concepts of discourse "about migrants" have acquired much more complex and differentiated semantics. This article is focused precisely on this very semantics based on a discourse analysis of the local press and interviews with the residents of the Khabarovsk Krai.
\end{abstract}

Keywords: migrant, migration, flow culture, discourse, host community, Russian Far East.

The study was partially carried out with the financial support of the Russian Foundation for Basic Research within the framework of a scientific project No. 18-012-00537.

Research area: sociological sciences.

Citation: Bliakher, L.E., Ivanova, A.P. (2020). Flow community, or why nobody speaks "about migrants" in the Khabarovsk Krai. J. Sib. Fed. Univ. Humanit. Soc. Sci., 13(5), 639-649. DOI: 10.17516/19971370-0595.

\footnotetext{
(C) Siberian Federal University. All rights reserved

* Corresponding author E-mail address: Leonid743342@mail.ru ORCID: 0000-0002-0610-9395 (Bliakher)
} 
Migration and migrants from neighbouring countries are increasingly becoming a stable phobia in Russian mass consciousness, actively promoted both in the academic discourse (Perepelkin, Stel'makh, 2005) and in the media (Varganov, 2012). As linguistic studies show, the number of positive definitions of the neutral concept of "migrant" is almost three times lower than the number of negative ones $(8 / 21)$. Almost half of the articles (48\%), which in one way or another touch upon the topic of migration and which contain the concept of "migrant" (Sherman, 2014), refer to migrants as "unwanted", "illegal", "criminal", etc. Even in "neutral" interviews with official proxies for the state migration policy, there is apparently negative discourse about migrants which is supported by expressions such as "restrict", "strengthen control", "conduct regular raids", etc.

At the same time, the existence of fundamentally different social, economic, natural and demographic conditions in different regions of the country (Zubarevich, 2010) leads to the fact that the discourse that has developed at the federal level takes a different turn in different areas and has varying "popularity" (Bliakher, Grigorichev, 2015). There is certain specificity in the Far East region, which acts as the geographical area of study for the present research. This article pinpoints the specifics of using the term "migrant" and focuses on the related discourse in the Russian Far East. The purpose of the article is not only an attempt to describe this specificity, but to identify those special social, demographic, historical and economic conditions that determine precisely this use of "migration discourse".

The empirical basis of our research is the discourse analysis of the materials derived from 4 major newspapers published in Khabarovsk and Vladivostok ("Tikhookeanskaia Zvezda" (meaning "Pacific star"), "Zolotoi rog" ("Golden horn"), "Amurmedia", and "Konkurent" ("Competitor")) over the past four years (20152019). Moreover, we took an advantage of a series of informal interviews with residents of the Far East, collected by one of the authors in 2013-2016 thanks to the support of the "Khamovniki Foundation" (32 interviews in total). Interviews were also subjected to discourse analysis. The purpose of the analysis was to identify the context of the term's usage and the discourse which the theme of migration generates, as well as the positive, neutral and negative connotations associated with it.

The interviewees included state and municipal employees (9), entrepreneurs, including foreign citizens (16), employees of the Ministry of Internal Affairs (2), scientists and teachers (2), and journalists (3). To take into account the current situation, the interview collection was supplemented by 3 interviews recorded by the author in 2019 as his own initiative. The choice of media was conditioned by two circumstances. Firstly, these newspapers are types of media with the largest circulation (they have the most visited sites), and secondly, they published articles about migrants or used the concept of "migrants" more commonly than others. We took a liberty of not taking into consideration the slight increase in the number of publications about migrants associated with the events in Yakutsk in March 2019 due to their deliberate hype, which nevertheless quickly faded away.

\section{Discourse about migrants \\ in the Far East}

We have already highlighted above certain specifics of the discourse about migrants in the Far East region. Despite the fact that our empirical material concerns only the southern part of the region, which stretches from North to South for more than four thousand kilometers, it seems that the situation is most acute in the south, since the number of migrants in the northern territories is negligible, and migrants themselves rarely show a desire to stay there after the end of their contracts. The episodic outbreaks of anti-migrant sentiments in 2012 in Kamchatka and 2019 in Yakutsk do not change the general picture and, as a rule, they are a form of shifting discontent from a prohibited object to a permitted one. So, what is the discourse about migrants and migration in the Russian Far East?

In each of the analyzed papers, articles on migrants and migration are quite a common thing. During the period under review, the topic was covered 223 times in the "Tikhookeanskaia zvezda" newspaper, 461 times 
in the "Amurmedia" electronic newspaper, 226 times in the "Zolotoi rog" newspaper, and 119 times in the "Konkurent" newspaper. But the very use of the term in publications is quite peculiar. Based on the analysis of dictionaries and articles in the media, N.N. Kasatkina and D.A. Smirnova (Kasatkina, Smirnova, 2017) elicited a number of synonyms for the word "migrant" (migrant, transmigrator, expatriate, visitor, displaced resident, settler, colonist, uitlander, special immigrant, defector, asylee, frontiersman, oustee, newcomer, emigrant, foreigner). Against this background, the authors conclude that the term "migrant" is both the most used and the most general term in terms of coverage. Even this feature manifests the peculiarity of the region. The term "migrant", depending on the context in the regional discourse, is rather often replaced by the terms "newcomers", "settlers", "Gastarbeiter workers", "strangers", "compatriots", indicating their ethnic belonging (Chinese, Koreans, Uzbeks, Tajiks, etc.) with the attitude to different groups being fairly different.

Most often, negative connotations are caused by the immigrants from Central Asia. To a much lesser extent, these connotations can be attributed to immigrants from the Caucasus and Ukraine. There are almost no negative associations as regards the Chinese and Koreans. Minimal negative connotations accompany the concept of "Gastarbeiter workers". A bit more frequent is a negative context in relation to the concept of "former compatriots". This, apparently, arises from the once declared and failed program to attract "fellow countrymen" (Russian-speaking citizens of the CIS countries) to the region. The concept "settlers" turns out not to bring about negative connotations at all. The only negative context that was discovered is linked to the project of providing benefits and sizeable financial support to new residents of the region, which infuriated the author of the studied article. Support, in his opinion, is necessary for those who already live in the Far East, and not for those who may come there later. The largest number of objurgations are to be found in the articles about "strangers" and "settlers". Beyond that, for the most part this harsh criticism does not involve foreign citizens or representatives of a different culture.

Moreover, of the 223 articles in the "Tikhookeanskaia zvezda" newspaper (where the concept "migrants" (or its synonym) is the key one, only 71 are devoted to the "familiar" topic of migrants from neighbouring countries. Of these, 12 articles are concentrated on the need for migrants for the region and its development. 26 articles revolve around the specifics of the application of new legal norms in relation to migrants. 19 articles touch upon relatively neutral topics concerning the social adaptation of migrants. Only 14 articles in one form or another are directed against migrants. A similar ratio with insignificant deviations can be seen in other papers, too. This alone gives serious differences from the all-Russian discourse, where, as noted above, almost half of the articles are openly xenophobic in nature or apparently directed against migrants.

The overwhelming majority of publications are devoted to migration of a completely different sort: the outflow of the local population outside the region and the country, the desire of the authorities to attract new labour resources (at least it is declared as such) from other regions of Russia. In this case, former neighbours, friends, relatives, etc., found themselves in the position of migrants. It is understandable that the "permanently relocated for good" (the term by journalist O.N. Kriuchok) did not cause negative emotions. Instead, these people triggered maximum sympathy. It is worth mentioning that, as the interviews show, people who have left the Far East do not lose touch with the territory and the community. They act as the "springboard" for the new outflow of the residents of the Far East.

"No, it's not scary to leave. It's scary to stay. For example, my university group consisted of about twenty people. And only three or four people stay in the city. The rest have all left. Won't they help me for the first time? Of course, they will. They will help me to find housing and work" (male 28-year-old respondent, entrepreneur, interview of 2014).

A separate and relatively new topic is the outflow of population to the neighbouring countries of East Asia. The interviewees mentioned 
Russian immigrants to China, the Republic of Korea, Thailand, and Vietnam. Although this migration (for work and training) is thought of as temporary, and it is not always included in statistical indicators, as respondents noted, many people have been out of Russia for more than a decade. Little is written about these migrants. But they often emerge in interviews, acting as a link between local business circles and the business community of neighbouring countries.

A number of articles are dedicated to the most elusive group of migrants, those settlers who must arrive and, in a very small number, have already arrived in the region. Here, the ratio was meaningfully different. Actually, the immigrants themselves did not cause negativity if they did not demand "special benefits" for themselves. The outrage was caused by the fact that, from the point of view of the articles' authors, the ways used by government to attract people to the Far East were mythologization (a lie, embellishment of reality) of the image of the region itself or huge benefits. What is more, the living standards of the Far East themselves turned out to be very far from the declared and broadcast image. This motive is even more reflected in the interviews. Especially if the respondents associated the "migrants" with the "Muscovites" who "came and ruined everything here" (male 59-year-old respondent, municipal employee, interview of 2015). It is interesting that the majority of respondents, including civil servants of regional administrations, adhere to this position.

It is important to note that alongside with the negative connotations (the settlers deprive us of our jobs, worsen the environment, commit crimes, etc.) the prevailing concept in texts, articles and interviews is "migrants". When it comes to value-neutral or positive meanings, other concepts are more often used. Remarkably, this can be noted even within one interview, depending on the turn of thought. There is a dependence of the use of the concept (and the degree of negativity) on the level of statement's officialness. The more official status of the respondent or the interviewee from the publication is, the closer this discourse on migrants is to those described All-Russian forms, and the more often the term "migrant" is used. Meanwhile, when the discourse becomes private, related to the personal experience of the respondent, the respondents tend to use the wider range of concepts or to spot the distinctive differences between the migrants. But even in relation to a specific type of migrants (foreign citizens), the attitude to them as expressed in the regional discourse is enormously complex and opinions are divided. The next section will look into what kinds of migrants are and how attitudes towards them differ.

\section{Such very different migrants}

Research on migration today is one of the most popular areas in the social sciences (Iontsev, 1999). However, despite the difference in approaches and even scientific disciplines in which international migration is studied, foreign migrants, as a rule, are treated as a whole, perceived as a generalized image. This generalization is especially pronounced when it comes to the perception of migrants by the host community (Zamaraeva, 2014). Likewise, such generalization (migrants = "strangers") is not by all means unique to the Russian discourse on migration (Brettell, 2003).

Some signs of similar generalization of the migrant's image can be found in the corpus of texts we are studying.

"At that time (at the turn of the century the author's note), the Chinese used to work at construction sites. If someone else came across, a Korean or an Uzbek, he was a Chinese for us, anyway" (male 58-year-old respondent, entrepreneur, interview of 2016).

Yet, as the interview analysis shows, generalization here is associated with a specific space and particular activities. Judging by the interview texts, the term "migrants" signify not just foreign citizens, who are temporarily (or not temporarily) located in Russia, but a certain social and professional status of these people.

"Migrants, oh, they work at a construction site, they do repairs. What else? They clean the streets. It's clear. There are also migrants - lumberjacks and road workers. There are housekeepers. But the latter are mainly women. The elderly are looked after properly if their children have enough money. That's it. 
Also, migrants work as bus drivers. But this is already too much. They drive, as they do at home, in the mountains, riding their donkeys" (male 49-year-old respondent, municipal employee, interview of 2016).

Similar views were shared by other respondents. Even regarding sellers in markets and in stores, respondents found it difficult to answer whether these people were migrants or not. This point deserves special attention. "Migrants" (this very term is used) are people who are confined to a specific space, engaged in affairs renowned for relatively low prestige in the eyes of the local population. Moreover, within different contexts in the same interview, one and the same person can appear both as a "migrant" ("works as a 'migrant' in the cottage of some vile people") and as a "neighbour".

"We have a neighbour in our block of flats, an Uzbek. A good egg. He put things in order in his elevator landing area. He made others stop crapping in the stairwell. Such a calm man. Normal one" (male 47-year-old respondent, entrepreneur, interview of 2015).

Differentiation outside the space of "migrants" is quite complex and ambiguous. In the already quoted passage from the interview there is also a negative connotation (migrants as bus drivers). Here, it seems, two ideas have collided. The first is associated with a specific driving style in large Far Eastern cities (Pugachev, 2009). In the Soviet years, the transport network of cities hinged exclusively on industrial supply. Other types of vehicles were negligible in numerical terms. In the post-Soviet decades, the number of cars on the roads of large cities has increased by several times, while the expansion of the road transport network has lagged crucially behind this process. To compensate for this situation, the drivers have developed a system of informal rules of the road behaviour, the observance of which for local residents is no less necessary than compliance with official traffic rules. New drivers who do not follow informal rules "do not know how to drive" and "create a danger on the road", from the point of view of local residents. This idea was cited in three interviews and one article. Besides, there is a "second" factor. "Bus drivers" concept does not completely coincide with the image of the professional sphere of "migrants". The appearance of "migrants" here is considered as an intrusion in "our" space. The bus drivers may be foreign citizens. But not "migrants".

Despite the fact that the provision stated above seems completely absurd from a legal point of view, the respondents distinguished these concepts unequivocally. A person who has successfully adapted to the "non-migrant specific" sphere of activity ceases to be perceived as a migrant. Such people who have fallen out from the traditional areas of employment of "migrants" also quit the discourse about migrants.

"We think that mathematics is a Korean field of knowledge (laughs). In the whole department, one teacher only is not Korean. Good guy. Uzbek, it seems. Or Tajik. I do not remember. But he is persistent. He writes something all the time" (female 53-year-old respondent, teacher, interview of 2019).

There are social spaces, occupations taken by people with the legal status of migrants, but they fall into a different type of discourse. Most of all, this type of discourse resembles the discourse of the ethno-professional division of labour. Typically, a particular activity is marked as ethnically tagged. For instance, selling spicy salads in a market or in a store is the Korean sphere of work. At the same time, it does not matter that these dishes themselves have already become a commonplace. In the same way, gardening and melon farming were mentioned as ethnically specific in the interviews collected.

Roadside cafes, with rare exceptions, are divided into Armenian, Uzbek and Chinese. Herewith, the absence of at least one representative of the implied ethnic group does not undermine the marking itself. Apart from that, representatives of any ethnic group, including local residents of Slavic origin, can trade in Chinese stores, though these shops remain Chinese in the minds of residents and respondents.

Cheap hotels, shopping centres and kiosks are supposed to be Azerbaijani. In the perception of local residents, the production of furniture, transportation business, and some other 
types of activity look quite an Azerbaijani industry, too. At the same time, going beyond the familiar sphere is associated with difficulties, is a kind of heroic deed for those who embark on this road.

"When I arrived in Khabarovsk, I was told: 'you are Azerbaijani, so start a business'. I graduated from university at home. I am a psychologist. Only here it is impossible to have such a profession. Well, at least, it is very hard to get such a work. Bu it is easy to do business. Many countrymen, everything is well arranged" (male 43-year-old respondent, entrepreneur, interview of 2015).

Spices and fruits in the markets are traded by "Uzbeks," but not "migrants." The Uzbeks often act as owners of convenience stores, cafes with ethnic or "Pan-Asian" cuisine, which gradually replace Chinese fast food cafes.

The image about Chinese has gone through a rather long and complex evolution (Ryzhova, 2014). They were the first foreigners to appear in large numbers in the Far Eastern cities in the early 1990s. They were the most numerous "Gastarbeiter workers" at the turn of the century. They were to spawn a short period of xenophobia in the region. The reason for it is quite obvious: for many decades the basis of the self-consciousness of the region's inhabitants had been the idea about their region as an "outpost of the USSR in Asia. Moreover, this outpost was primarily oriented against China. The appearance of the Chinese in the streets of the Far Eastern cities in the early 1990s was seen as "surrender of the fortress" (Bliakher, 2004), as a defeat.

The Chinese, who have been capturing the Russian Far East, have been frequently mentioned in the written and oral discourse since the first half of the 1990s (Gel'bras, 2016). Later this concept became one of the "constructed threats" (like the threat of Islamic fundamentalism in Tatarstan), with the help of which the regional elites built relations with the federal centre. By the middle of the $2000 \mathrm{~s}$, the number of labour migrants from China had turned out to be so minute that the discourse itself was gradually disappearing. In any case, this trend concerns the territory of the Far East in the very least. Today the community speak about Chinese business, about Chinese tourists, about "Russians there" much more actively than about migrants from China. Only relics of xenophobia occasionally pop up in the media and in interviews with government officials. However, their frequency is not so great. Much higher interest is showed in interacting with Chinese business circles, universities, government agencies, etc. Middle-brow fear is now connected not with "Chinese migrants", but with the fact that "the Chinese will leave", and the region will turn out to be a "double periphery" for both the West and the East (Larin, 2018).

A separate and relatively new topic is Ukrainian immigrants. It is striking that in the interviews the term "settlers" was used only in relation to them and to Russian migrants from other regions. But even this group is not homogeneous in the perception of the region's population. Former migrants from Ukraine fall out of the discourse about migrants (even in the version of "migrants"), if they started to work according to their specialty at a new place of residence. They are perceived simply as "our own fellowmen", who have got in a difficult situation and deserve help and support. Migrants who "throw their weights around", who behave differently from what is accepted or expected from the local community, are treated quite the opposite. And although the interview concerned specifically migrants (refugees) from Ukraine, their falling out of the habitual discourse is the main source of social tension associated with migrants.

"That's how it was. These arrived ... from Donbass. Normal people bent over backwards, got help, found a job and that's it. They work, live, get settled. And there were others. Who said: 'We need work with salary not less than fifty $k$, with housing'. Fine. We found them even such jobs. The drivers for the intercity. Road builders. But they do not want to work there. They consider it hard job. But what do you want? To make a big salary and have an easy work, in the city, to sit in the office? Excuse me. This will not ever happen. They made a mess, they blew our minds. And they hit the road" (male 53-year-old respondent, civil servant, interview of 2016). 
It should be noted that, with the exception of these rather exotic circumstances, negative connotations do not address massively contracted workers for megastructures who have recently arrived in the region. They exist in their social niche, which is fully recognized by both the local community and the settlers themselves. In this regard, their existence does not give rise to a particular discourse. Even when certain incidents occur (for example, the struggle between "new" and "old" Muslims in the region), they are connected with the discourse about migration indirectly.

To explain this fact, one can certainly refer to the especial tolerance of the inhabitants of the region, their ability to negotiate. But it is much more rational, as we see it, to recall the features of the region's first settlement, the peculiarities of the functioning of the host community. The latter is to a minimum degree a certain permanent unit, being itself in a state of constant change. We used the term "flowing social community" to call this condition, which will be discussed further.

\section{Flowing community and migration flows}

Despite the fact that no one seems to particularly question the significance of international migration, and the number of migrants is measured by tens of millions of people (Deleva, 2010), migration continues to be thought of as a peripheral, derisory phenomenon in relation to the host community. Probably, as for the most of the host communities, this position is justified. Nonetheless, in the Far East of Russia (Remnev, 2004), more precisely, in its southern and coastal parts, which once formed the Amur General Governorate, this position is far from being always true. Starting from the $19^{\text {th }}$ century, the population of the region has experienced constant and critical interaction of incoming and outgoing demographic flows. The crisis at the enterprises of the cabinet of His Imperial Majesty and the abolition of serfdom entailed a massive outflow of the population. According to historians (Istoriia Dal'nego Vostoka..., 1990), the territory of the future General Governorate had lost three-quarters of the population by the $1860 \mathrm{~s}$. A huge amount of benefits, the allocation of 270 acres of land per family, the introduction of regular Dobroflot fishing company sailings and, finally, the construction of the railway, restored the number of the regional population. It continued to grow, despite all the vicissitudes of the First World War and the Civil War until 1925 (Osipov, 2012). There was no hunger, which was of a frequent occurrence at that time in the western territories of Russia. Outbreaks of violence occurred only occasionally (Smoliak, 2009). In fact, partisan detachments entered cities that did not mind being occupied.

But after the collapse of the Far Eastern Republic in 1922, the situation changed. The replacement of the surplus appropriation system by the tax in kind, which was gladly accepted by the rest of the country, did not bring joy to the Amur villages. Here, the people had not got used to the features of the Bolshevik management. Additionally, the very taxed "kulaks" constituted the core of the "Amur partisans," who had once decided that Kolchak had been the worst evil (Sanachev, 1992). In 1925, the Zeya Uprising began, covering the most populated and developed territories of the former General Governorate. It was crushed by an army with armoured trains, aircraft and artillery. After the suppression of the uprising, there was a massive, incomparable with the "White Guard emigration", peasants flee "across the river" to China.

The richest region of the country inherited by the Soviets turned out to be almost empty and poor in the shortest period. The population decreased dramatically again (Galliamova, 2012). The authorities began a series of attempts to somehow populate empty lands. On this count, one can also remember about the forced relocation of exiled ("dispossessed") peasants, the organization of GULAG branches, the resettlement project for "working Jews", "party and Komsomol calls", and other resettlement initiatives (Bliakher, 2014). The opposite direction of flow was less organized, but the flows of those who did not get accustomed in these areas and were able to break away were no less numerous. At the same time, it is worth considering that a significant part of the population of the Far Eastern Territory was made up of military personnel of the Red Banner Far 
Eastern Military District and members of their families. It is very difficult to attribute them to the permanent population (Tkachev, 2011).

In other words, during the Soviet period, a specific population model was formed, consisting of incoming and outgoing demographic flows with an extremely small number of "regional core", which accounted for less than one sixth of the population. We called this type of population creation "flowing social community".

"We are all migrants, or rather settlers. I was born in Ufa. You were born in Dushanbe. He, someone, - in Riga or Minsk. We all came from somewhere. Now we are the Far Easterns. It just happened. But our children are no longer Far Easterners. Yours are in St. Petersburg, mine live in Moscow. We will leave, new ones will arrive. It has always been like this" (male 58-year-old respondent, civil servant, interview of 2016).

As for this model of settlement of the region, it is worth noting three circumstances that are highly important for our research. Firstly, the main population of the modern Far East was formed from those who remained after the cessation of the departure of representatives of the incoming demographic flows (immigrants). On top of everything, they stayed not only after the 1920s-1930s outflow, but mainly in the 1950s-1970s (after the builders and workers of the defense giant plants, builders of BAM had left). Being migrants themselves, not rooted in the region (the third generation as a maximum), the Far Easterns fully retain ties with the place from where they once arrived. The latter factor greatly facilitates the achievement of the main goal of every resident of the region - departure.

Secondly, since most of the population of the territory consisted of settlers, the arrival of new people here was perceived as a routine, rather than a momentous event, involving a special reflection. After all, the "locals" had their own resettlement experience, which included the practice of helping new settlers, assimilating them in an existing system of social connections. The indignation of the "locals" (earlier migrants themselves) was caused by the situation when new migrants were given a weightier amount of benefits than them.
"I don't know about the others, but it just gets me mad when they begin to argue that they need to pay extra money to those who will move to the Far East. Why are they to get the money? What about us, those who have lived here all our lives, are we no longer taken into account? Aren't they interested in us? Maybe it's better to pay us extra so that we don't leave? No, they are not satisfied with present population, they need new ones" (female 46-year-old respondent, municipal employee, interview of 2019).

Leaving the region became (and was perceived) not as a step of despair or the result of "pushing out" (Arago et al., 1998), but as a normal and completely routine career stage. Those leaving should have been replaced by new settlers, which is also quite normal. As a result, the very fact of the appearance of new people in the region, making up for the departure of the "locals", caused neither rejection nor negative emotions.

Thirdly, the settlement was carried out by the entire USSR, including the republics that became independent states after 1991. Hence, abundant ethnic groups have formed in the cities and towns of the region, which were perceived as no less "our own" than any other residents of the region. Accordingly, in the post-Soviet period, a substantial part of the migrants who had been ethnically labelled in the western regions arrived in the Far Eastern region as "relatives and acquaintances of local residents". Consequently, in the vast majority of situations, they did not fall into the prevailing "discourse about migrants".

\section{Conclusion}

Thus, the prevailing (and described in the present article) "migrant discourse" is partially preserved in the region. However, there is a quite stable and measurable specificity. The number of people being categorized as migrants is significantly less than in European and even Siberian regions. This is due not so much to the fact that there are fewer people with the status of "migrant" here, but to the fact that a large or at least a telling part of them are perceived not as migrants, but differently.

Regional ideas about "migrants" include people who have signed long-term contracts 
to work at large construction sites, mines and opencasts in the region, and representatives of a very specific circle of professions. Moreover, these people, as a rule, are not connected with the region and the local population. They do little prestigious jobs, which most often suits local residents who are not particularly keen to take these places. The rest people arriving in the Far East either do not have the status of a labour migrant (tourists, business partners, scientists at conferences, etc.), or are relatives of completely "local" representatives of ethnic groups. They are evidently described by a different discourse, enter other status-role niches that are created in the region, whose population has been created according to the model of constant migration.

\section{References}

Arago, J., Massey, D., Koucouci, A., Pellegrino, A., \& Taylor, E.J. (1998). Worlds in Motion: Understanding International Migration at the End of the Millenium. Oxford: Oxford University Press, $376 \mathrm{p}$.

Bliakher, L.E. (2004). Potrebnost' v natsionalizme, ili natsional'noe samosoznanie na Dal'nem Vostoke Rossii [The need for nationalism, or national self-identity in the Russian Far East]. In Polis. Politicheskie issledovaniia [Polis. Political research], 3, 44-54.

Bliakher, L.E. (2014). Iskusstvo neupravliaemoi zhizni: Dal'nii Vostok [The Art of Uncontrolled Life: The Far East]. Moscow, "Europe", 208 p.

Bliakher, L.E., Grigorichev, K.V. (2015). Vgliadyvaias' v zerkala: smyslovye transformatsii obraza Kitaia $\mathrm{v}$ rossiiskom sotsiume [Peering into mirrors: semantic transformations of the image of China in Russian society]. In Politia, 1, 24-38.

Brettell, C.B. (2003). Anthropology of migration. Blackwell Publishing Ltd, 135 p.

Deleva, Ž. (2010). Conceptualizing Migration in Europe: Selected Theoretical Approaches. In Working Paper, 04, 3-40. Institute of European Studies and International Relations, Faculty of Social and Economic Sciences, Comenius University.

Galliamova, L.I. (2012). Dal'nii Vostok SSSR v gody nepa: tendentsii i osobennosti sovremennoi istoriografii [The Far East of the USSR during the NEP: trends and features of modern historiography]. In Rossiia i Aziatsko-Tikhookeanskii region [Russia and the Asia-Pacific Region], 3, 55-71.

Gel'bras, V.G. (2016). Kitaiskaia trudovaia migratsiia v Rossiiu: chto ona sulit nashei strane [Chinese labour migration to Russia: what it brings to our country]. In Aziia i Afrika segodnia [Asia and Africa to$d a y], 5,50-54$.

Iontsev, V.A. (ed.) (1999). Mezhdunarodnaia migratsiia naseleniia: Rossiia i sovremennyi mir [International migration: Russia and the modern world], 2. Moscow, Dialogue-MSU, 124 p.

Istoriia Dal'nego Vostoka SSSR. Istoriia Dal'nego Vostoka SSSR v epokhu feodalizma i kapitalizma (XVII v. - fevral' 1917 g.) [History of the Far East of the USSR. History of the Far East of the USSR in the era of feudalism and capitalism (17th century - February 1917)]. Moscow, "Nauka", 1990, $471 \mathrm{p}$.

Kasatkina, N.N., Smirnova, D.A. (2017). Postroenie nominativnogo polia kontsepta "Migrant" na materiale statei onlain-versii rossiiskikh gazet 2010-2011 and 2015-2016 gg. [Creating nominative field of the concept "Migrant" on the basis of articles from online Russian newspapers]. In Sotsial'nye i gumanitarnye znaniia [Social and humanities knowledge], 3, 1, 69-75.

Larin, V. (2018). Novaia geopolitika dlia Vostochnoi Evrazii [New geopolitics for Eastern Eurasia]. In Rossiia v global'noi politike [Russia in global politics], 5, available at: https:/globalaffairs.ru/number/ Novaya-geopolitika-dlya-Vostochnoi-Evrazii-19739 (date of access: 3.03.2019).

Massey, D.A. (2002). Synthetic theory of international migration. In World in the mirror of international migration, 10, 143-153.

Osipov, Iu.N. (2012). Krest'iane-starozhily Dal'nego Vostoka Rossii: 1855-1917 gody. [Old-time peasants in the Russian Far East: 1855-1917]. Vladivostok, Publishing House of the Vladivostok State University of Economics and Service, $251 \mathrm{p}$. 
Perepelkin, L.S., Stel'makh, V.G. (2005). Neligitimnaia immigratsiia i neofitsial'naia zaniatost' v Rossiiskoi Federatsii: zlo, blago ili neizbezhnost'? [Illegal immigration and informal employment in the Russian Federation: evil, good or inevitability?]. In Obshchestvo i ekonomika [Society and Economics], 4, 49-62.

Pugachev, I.N. (2009). Dorozhnoe dvizhenie i bezopasnost' gorodskoi zhizni [Traffic and the safety of urban life]. In Napravlenie - Dal'nii Vostok [Direction - Far East], 3, 84-87.

Remnev, A.V. (2004). Rossiia Dal'nego Vostoka: Imperskaia geografiia vlasti XIX-nachala XX veka [Russia in the Far East: Imperial geography of power in the 19th - early $20^{\text {th }}$ centuries]. Omsk, Publishing House of the Omsk State University, 552 p.

Ryzhova, N. (2014). National border, administrative rent and informality: Market Entrance for Chinese traders and Farmers. In Eurasia Border Review (Japan), 5 (1), 77-94.

Sanachev, I.D. (1992). Krest'ianskoe vosstanie na Amure - kulatskii miatezh ili shag otchaianiia? [A peasant uprising on the Amur - a kulak rebellion or a step of despair?]. In Vestnik Dal'nevostochnogo otdeleniia Rossiiskoi akademii nauk [Bulletin of the Far Eastern Branch of the Russian Academy of Sciences], 3-4, 32-39, 27-37.

Sherman, E.M. (2014). Obraz "chuzhogo": portret migrantov v SMI, arkhetipy kollektivnogo bessoznatel'nogo [The image of the "alien": portrait of migrants in the media, archetypes of the collective unconscious], available at: http://ashpi.asu.ru/ic/?p=2756 (date of access: 04.03.2019).

Smoliak, V.G. (2009). Mezhdousobitsa: Po sledam nizhneamurskoi tragedii [Civil feud: Following the Lower Amur tragedy]. Khabarovsk, Khabarovsk Regional Museum named after N.I. Grodekov, $128 \mathrm{p}$.

Tkacheva, G.A. (2013). Oboronnyi potentsial Dal'nego Vostoka SSSR v 1930-40-e: osnovnye teoreticheskie podkhody [The defense potential of the Far East of the USSR in the 1930-40s: basic theoretical approaches]. In Sed'mye Krushanovskie chteniia 2011. Tikhookeanskaia Rossiia v mezhtsivilizatsionnom i obshcherossiiskom prostranstve: proshloe, nastoiashchee, budushchee [The Seventh Krushanov's Readings 2011. Pacific Russia in the inter-civilization and all-Russian space: past, present, future], 415-423. Vladivostok, "Dalnauka".

Varganova, O.F. (2012). Obraz trudovogo migranta v SMI (po rezul'tatam content-analiza) [The image of a labour migrant in the media (based on the results of content analysis)]. In Istoricheskaia $i$ sotsial'no-obrazovatel'naia mysl (Historical and Socio-Educational Idea), 3, available at: https://cyberleninka. ru/article/n/obraz-trudovogo-migranta-v-smi-po-rezultatam-kontent-analiza (date of reference: 06.04.2019).

Zamaraeva, Iu.S. (2014). Osobennosti etnicheskoi migratsii v sotsial'no-psikhologicheskom vospriiatii (na materiale analiza rezul'tatov eksperimenta po metodike "Seriinye tematicheskie assotsiatsii") [Features of ethnic migration in socio-psychological perception (the analysis of the results of the experiment based on the method of "Serial thematic associations"). In Sotsiodinamika [Sociodynamics], 9, 63-82.

Zubarevich, N.V. (2010). Regiony Rossii: neravenstvo, krizis, modernizatsiia [Regions of Russia: inequality, crisis, modernization]. Moscow, Independent Institute for Social Policy, available at: https://gtmarket.ru/files/article/5279/Regions_of_Russia_2010_Natalia_Zubarevich.pdf (date of access: 8.05.2020). 


\title{
Проточная общность, или Почему \\ в Хабаровском крае не говорят «о мигрантах»
}

\author{
Л.Е. Бляхер, А.П. Иванова \\ Тихоокеанский государственный университет \\ Российская Федераџия, Хабаровск
}

\begin{abstract}
Аннотация. Одной из специфических черт большинства дальневосточных территорий является крайне слабое, во всяком случае по сравнению с европейскими губерниями страны, развитие дискурса «о мигрантах». Он остается элементом узкопрофессиональных рассуждений о миграции как феномене. Причем чаще относится не к человеку, приехавшему на Дальний Восток (Хабаровский край), но к прежнему жителю региона, уехавшему в иные дали. В отношении прибывающих в край лиц используется гораздо более «дробная» терминология, которая часто не имеет оценочной коннотации в отличие от концепта «нелегальный мигрант».

Причиной такого не вполне обычного для страны словоупотребления, на наш взгляд, выступает особенность формирования регионального сообщества. На протяжении большей части XX века и до настоящего времени население региона формировалось за счет приезжих. Причем в силу полиэтнического характера СССР приезжие эти принадлежали к самым разным этносам. При этом отток населения, не прекращавшийся и в самые благополучные годы, приводил к тому, что примерно каждые 20 лет состав населения очень существенно изменялся. В результате понятия дискурса «о мигрантах» приобрели гораздо более сложную и дифференцированную семантику. О ней применительно к территории Хабаровского края на основе дискурс-анализа местной прессы и интервью с жителями региона и пойдет речь в статье.
\end{abstract}

Ключевые слова: мигрант, миграция, проточная культура, дискурс, принимающее сообщество, Дальний Восток России.

Исследование частично выполнено при финансовой поддержке РФФИ в рамках научного проекта № 18-012-00537.

Научная специальность: 22.00.00 - социологические науки. 